\title{
UPAYA PENINGKATAN HASIL BELAJAR MATA PELAJARAN AGRIBISNIS TERNAK UNGGAS PETELUR MATERI PENGADAAN BIBIT UNGGAS PETELUR MELALUI PENERAPAN MODEL PROBLEM BASE LEARNING
}

\author{
Ramli \\ SMK Negeri 2 Negara \\ e-mail: ramli123@gmail.com
}

\begin{abstract}
Abstrak
Berdasarkan pengamatan proses pembelajaran dan tes hasil belajar pada mata pelajaran Agribisnis Ternak Unggas Petelur dengan materi pengadaan bibit ternak ungags petelur siswa kelas XI ATU 2 Program Kehlian Agribisnis Ternak Unggas, SMK Negeri 2 Negara, yang dilakukan selama Siklus I dan II dapat dijelaskan sebagai berikut: bahwa pada prasiklus rata-rata nilai 63,7 dengan ketuntasan belajar yang dicapai $53,8 \%$, pada siklus I rata-rata nilai 75,3 dengan ketuntasan belajar $80,8 \%$ dan pada siklus II rata-rata nilai 80,1 dengan ketuntasan belajar $100 \%$ dengan demikian bearti terdapat peningkatan hasil belajar yang sangat signifikan yaitu dari prasiklus ke siklus I 11,6 , dari siklus I ke silus ke II 4,8 atau peningkatan ketuntasan belajar dari pra siklus ke siklus I 27\% dan dari siklus I ke siklus II 19,2\%. Dari hasil penelitian tersebut dapat diambil kesimpulan bahwa dengan penerapan pembelajaran problem base learning pada mata pelajaran agribisnis ternak ungags petelur dapat meningkatkan hasil belajar siswa Kelas XI ATU 2 Program Keahlian Agribisnis Ternak Unggas SMK Negeri 2 Negara
\end{abstract}

Kata-kata kunci : Problem Base Learning ,Hasil Belajar, Pengadaan Bibit Unggas Petelur

\begin{abstract}
Based on observations of the learning process and learning achievement test in Agribusiness Poultry Laying subjects with materials for the procurement of laying poultry breeds for students in eleventh grade ATU 2 Poultry Agribusiness Endurance Program, SMK Negeri 2 Negara, conducted during Cycle I and II can be explained as follows: that in the pre-cycle average value of 63.7 with mastery learning achieved $53.8 \%$, in the first cycle the average value of 75.3 with mastery learning $80.8 \%$ and in the second cycle an average value of 80.1 with completeness learning $100 \%$ thus means there is a very significant increase in learning outcomes from pre-cycle to cycle I 11.6, from cycle I to silus II II 4.8 or increase mastery learning from pre cycle to cycle I $27 \%$ and from cycle I to second cycle $19.2 \%$. From these results it can be concluded that the application of problem base learning in the subjects of laying livestock agribusiness can improve student learning outcomes in Class XI ATU 2 Poultry Agribusiness Expertise Program at SMK Negeri 2 Negara.
\end{abstract}

Keywords: Problem Base Learning, Learning Outcomes, Procurement of Laying Poultry 


\section{Pendahuluan}

Negara Berdasarkan pengamatan yang dilakukan Peneliti di lapangan, terhadap proses belajar mengajar mata pelajaran Agribisnis Ternak Unggas Petelur pada materi pengadaan bibit unggas Petelur yang dilaksanakan di kelas XI 2 Agribisnis Ternak Unggas Semester II SMK Negeri 2 Negara, dimana dalam pengamatan tersebut peneliti melihat bahwa siswa masih perlu banyak bimbingan dari guru mata pelajaran yang memberikan materi tentang pengadaan bibit unggas petelur secara intensif. Karena dalam mengaplikasikan pengetahuan akademik kedalam praktik pengadaan bibit unggas petelur nampak bahwa proses yang dilakukan siswa belum sesuai dengan prosedur yang terdapat dalam teknik yang terkait dengan menentukan bibit unggas petelur yang berkualitas sebagai sesuai dengan langkah seberikjut : 1) Menentukan Jenis-jenis Starin/bibit Unggas Petelur yang berkualitas, 2) Menganalisis terhadap karakteristik masing-masing Strain, 3) Menerapkan teknik memperoleh bibit anak unggas petelur yang berkualitas baik, 4) Menentukan jadwal kandangan bibit, agar bibit dapat tumbuh dengan sehat dan utuh, 5) Mempersiapkan kedatangan bibit, 6) Melakukan seleksi bibit anak unggas petelur, sehinggamemperoleh bibit yang berkualitas tinggi, 7) Melakukan seleksi bibit /pullet, an 8) Menangani bibit anak unggas petelur yang baru datang

Setelah diperhatikan tentang keterlaksanaan pembelajaran maka dapat ditarik suatu kesimpulan bahwa dalam pembelajaran guru mengajar diawali dengan teori atau pengetahuan. Tidak banyak waktu yang diberikan dalam menerapkan pengetahuan tersebut kedalam praktik. Selanjutnya setelah dilakukan latihan simulasi dalam praktik pengadaan bibit unggas petelur maka siswa nampak belum memahai dengan baik tentang prosedur pengadaan bibit unggas petelur dengan baik.

Pembelajaran seperti ini membuat siswa kurang mampu menyerap materi yang disampaikan guru sehingga hasil belajar yang dicapai siswa rendah. Dari pelaksanaan tes awal prasiklus yang dilakukan pada tahap awal dari penelitian ini nilai rata-rata yang dicapai siswa rendah yaitu 63,7 dengan ketuntasan belajar mencapai 53,8\%.Dalam hal ini nampak bahwa Guru sebagai sumber utama dalam kegiatan belajar mengajar di kelas dan keterlibatan siswa masih kurang. Siswa menjadi kurang kreatif karena pembelajaran berlangsung satu arah (teacher Centred) dan lebih banyak penyampaian materi dengan informasi dalam bentuk ceramah. Oleh karenanya Peneliti perlu melakukan perbaikan-perbaikan agar hasil belajar siswa dapat ditingkatkan.

Beradasarkan hal tersebut maka judul yang diangkat dalam penelitian ini adalah: Upaya Peningkatan Hasil Belajar Mata Pelajaran Agribisnis Ternak Unggas Petelur Materi Pengadaan Bibit Unggas Petelur Melalui Penerapan Model Problem Base Learning Pada Siswa Kelas XI. 2 Agribisnis Ternak Unggas Semester II SMK Negeri 2 Negara Tahun Pelajaran 2018/2019, setelah diperhatikan tentang keterlaksanaan pembelajaran maka dapat ditarik suatu kesimpulan bahwa dalam pembelajaran guru mengajar diawali dengan teori atau pengetahuan. Tidak banyak waktu yang diberikan dalam menerapkan pengetahuan tersebut kedalam praktik.

Berdasarkan latar belakang yang telah disampaikan, maka rumusan masalah dalam penelitian ini adalah: Apakah Penerapan model pembelajaran Problem Base Learning dapat meningkatkan hasil belajar mata pelajara Agribisnis Ternak Unggas Petelur, dengan materi Pengadaan Bibit Unggas Petelur bagi siswa kelas XI.2 Agribisnis Ternak Unggas di Semester II di SMK Negeri 2 Negara ?'

Tujuan yang ingin dicapai dalam penelitian ini sesuai dengan rumusan masalah diatas adalah sebagai berikut: Untuk meningkatkan hasil belajar mata pelajaran Agribisnis Ternak Unggas Petelur dengan materi Pengadaan Bibit Unggas Petelur bagi siswa kelas XI.2 Agrebisnis Ternak Unggas di SMK Negeri 2 Negara, melalui penerapan model pembelaharan Problem Base Learning

Hasil penelitian ini diharapkan bermanfaat untuk: 1) Peneliti sendiri sebagai guru mata pelajaran Agribisnis Ternak Unggas Petelur untuk dapat mengembangkan diri dalam penelitian tindakan kelas daaan dapat menggunakan model pembelajaran Problem Base Learning, 2) Guru Kejuruan Agribisnis Ternak Unggas, sebagai alternative strategi pembelajaran yang dapat 
digunakan untuk meningkatkan hasilbelajar siswa, dan 3) Kepala Sekolah, sebagai pengambil kebijakan di sekolah untuk mengadakan model-model pembelajaran di kelas dan Program Keahlian yang lain

\section{Metode}

Tempat Metode yang digunakan dalam penelitian ini adalah deskriptif analisis hasil Penelitian Tindakan Kelas (PTK), yaitu studi yang digunakan untuk mengumpulkan data, mendeskripsikan, mengolah, menganalisa, menafsirkan dan menyimpulkan data sehingga diperoleh gambaran yang sistematis.

Penelitian ini dilakukan di Kelas XI.2 Agribisnis Ternak Unggas semester II SMK Negeri 2 Negara. Subjek penelitian adalah siswa kelas XI. Agribisnis ternak Unggas sebanyak 26 orang siswa, dilihat hasil belajarnya kelas tersebut belum mencapai nilai yang sesuai dengan standar nilai yang telah ditentukan sekolah yaitu 70 . Kelas itu dijadikan sebagai subjek penelitian karena rata-rata hasil tes awal (pra siklus) hanya mencapai nilai 63,7 dengan ketuntasan belajar mencapai 53,8\% nilai rata-rata dibawah KKM. Kondisi demikian perlu segera ditangani untuk dilakukan perbaikan - perbaikan, karena rendahnya hasil belajar mata pelajaran agribisnis unggas petelur dengan materi pengadaan bibit anak unggas petelur yang dicapai oleh siswa. Guru belum menentukan strategi/metoda mengajar yang tepat dilihat dari hasil pengamatan awal, sehingga hasil yang dicapai pada tes prasiklus rendah.

Hal ini berarti strategi /metoda yang digunakan guru dalam mengajar baik pada pembelajaran akademik maupun pembelajaran praktek menggunakan metoda mengajar konvensional yang hanya berpusat pada guru ( Teacher Centred), sehingga siswa kurang optimal pemahamannya dalam menyimak konsep materi pelajaran kejuruan yaitu tentang pengadaan bibit anak unggas petelur. Penelitian ini dilakukan pada semester dua tahun pelajaran 2018/2019. Dilakukan sebanyak 2 siklus. Masing-masing siklus terdiri 2 kali pertemuan.

Waktu Penelitian mulai dari Perencanaan sampai dengan penulisan laporan hasil penelitian tersebut mulai dari bulan Januari s.d Juni tahun 2019, pada semester dua tahun pelajaran 2018/2019. Waktu untuk melaksanakan tindakan mulai dari siklus I s.d siklus II adalah selama 3 bulan. Tindakan dilakukan terhadap siswa yang belum mencapai target pada prasiklus dan siklus I

Subyek Penelitian ini adalah siswa kelas XI.2 Agribisnis Ternak Unggas semester II SMK Negeri 2 Negara sebayak 26 orang hasil belajar yang dicapai siswa sebagai tolok ukur dalam melakukan tindakan-tindakan. Pelaksnaan Penelitian Tindakan kelas ini di kosentrasikan pada hasil pembelajaran yang dicapai oleh siswa terhadap mata pelajaran agribisnis unggas petelor dengan materi pengadaan bibit anak unggas petelur.

Variabel Input adalah siswa kelas XI.2 Agribisnis Ternak semester dua SMK Negeri 2 Negara, Sumber Belajar, Prosedur evaluasi, Lingkungan belajar, sarana pembelajaran. Variabel Proses pelanggaran KBM seperti interaksi belajar mengajar, kemampuan guru terhadap materi pelajaran yang diajarkannya, persiapan mengajar guru, kelengkapan dokumen mengajar guru, keterampilan bertanya oleh siswa, gaya mengajar guru, cara belajar siswa, implementasi berbagai metoda mengajar di kelas, penggunaan media pembelajaran. Variabel output seperti rasa keingintahuan siswa yang tinggi, kemampuan siswa mengaplikasikan pengetahuan, motivasi siswa, hasil belajar siswa, sikap terhadap pengalaman belajar yang telah digelar melalui tindakan perbaikan, kemampuan guru dalam melakukan refleksi kepada siswa .

Rancangan penelitian tindakan kelas di pusatkan pada situasi dalam proses social belajar di kelas berlangsung secara kolaborasi dalam pelaksanaan proses pembelajaran di kelas. Penyusunan rancangan penelitian ini dilakukan atas dasar empiris yang didukung program penelitian tindakan kelas.

Pengumpulan data dalam Penelitian Tindakan Kelas ini menggunakan instrumen dan langkah-langkah yang terdiri dari : a) Instrumen Tes Uji Kompetensi, b) Angket siswa, c) Lembar observasi, d) Instrumen Wawancara, dan e) Refleksi 
Pembelajaran dilaksanakan sesuai dengan rencana yang telah dirancang dalam Penelitian ini. Rancangan penelitian yang telah disusun menjadi acuan dalam penelitian ini agar pelaksanaan penelitian konsisten dengan rencana yang telah ditetapkan. Segala sesuatu yang akan digunakan dalam penelitian ini termasuk perangkat dokumen dipersiapkan sebelumnya, agar pelaksanaan penelitian dapat berjalan dan terlaksana dengan baik. Guru mempersiapkan strategi, materi dan perangkat sesuai rencana yang telah disusun demikian pula siswa yang dijadikan subjek yaitu kelas XI Agribisnis Ternak Unggas pada semester II Pembelajaran agribisnis ternak unggas petelur dengan materi pengadaan bibit unggas petelur dipersiapkan sebelumnya untuk menghindari terjadinya tumpang tindih terhadap waktu pembelajaran mata pelajaran lainnya. Kegiatan observasi yang akan dilakukan secara berkoordinatif dengan guru mata pelajaran lainnya sebagai observer untuk mengambil hasil observasi.

Hasil yang didapat pada tahap observasi kemudian dianalisis bersama-sama antara peneliti dengan observer. Dengan berpatokan pada hasil analisis tersebut, guru dapat merencanakan tindak lanjut pada siklus berikutnya. Observasi dilakukan dengan menggunkan lembar onservasi.

Indikator kinerja dibutuhkan dalam Penelitian Tindakan Kelas (PTK) ini agar pelaksanaannya dapat meningkatkan hasil belajar siswa sesuai dengan apa yang dikehendaki bisa semakin baik. Di harapkan dalam penelitian ini terdapat peningkatan hasil yang maksimal dengan capaian rata-rata nilai standar bahkan diatas standar yang diperoleh dari setiap siklus. Dimana nantinya akan berdampak pada peningkatan terhadap kemampuan siswa dalam memahami materi pembelajaran tentang pengadaan bibit anak unggas petelur dengan baik. Hasil akhir yang diperoleh adalah meningkatnya nilai akademis siswa pada mata pelajaran agribisnis unggas peteur dengan materi pengadaan bibit anak unggas petelur bagi siswa kelas XI. Agribisnis ternak SMK Negeri 2 Negara menjadi lebih baik.

Analisis data menggunakan teknik kuantitatif berupa perhitungan dan teknik kualitatif berupa uraian. Setelah data terkumpul dan diperiksa, bila memenuhi persyaratan, maka data tersebut diolah dan dihitung presentasenya. Sedangkan langkah-langkahnya adalah sebagai berikut : 1. Mengumpulkan data, 2. Menyeleksi data, 3. Mengklarifikasi data, dan 4. Menghitung prosentase

Data dari hasil Penelitian secara sistematis dan kemudian ditarik suatu kesimpulan umum, baik secara narasi maupun dalam bentuk grafik. Pelaksananaan Penelitian Tindakan Kelas ( PTK) ini terdiri dari dua siklus, dimana setiap siklus terdiri dari empat komponen yaitu : 1. Tahap Perencanaan (Planning).

Pada tahap ini Peneliti menyusun Rencana Pembelajaran (RPP), materi pokok yang akan diajarkan kepada siswa bersama dengan Indikatornya. Pelaksanaan Pada siklus I, II, di rencanakan dalam persiapan ini. Selanjutnya dilakukan pemilihan masalah yang potensial diangkat dalam penelitian ini atau sesuai judul yang telah disetujui dalam proposal Penelitian Tindakan Kelas (PTK) ini. Pelaksanaan Studi Pendahuluan, melakukan perumusan masalah, memilih pendekatan yang akan diterapkan dalam penelitian ini, kemudian menentukan variabel dan menentukan sumber data. Mempersiapkan alat dan bahan adalah hal penting dalam penelitian ini, dan penyusunan instrumen tes uji kompetensi serta lembar observasi.

2. Pelaksanaan tindakan (Acting),

Kegiatan yang dilakukan pada tahap ini adalah melaksanakan pembelajaran sebagaimana scenario pembelajaran yang telah ditetapkan pada RPP. Mengamati dokumen pembelajaran yang telah disiapkan oleh guru mata pelajaran bersangkutan.

3. Pengamatan (Observasi).

Pada tahap ini dilakukan proses observasi terhadap pelaksanaan tindakan menggunakan lembar observasi yang telah dibuat. Semua aktivitas pembelajaran peneliti amati dengan tim observasi yang telah diajak bekerja sama atau berkolaborasi dalam melakukan Penelitian Tindakan Kelas (PTK) ini.

Setiap siklus saling berkaitan dan berhubungan, karena hasil refleksi akan digunakan sebagai acuan untuk perbaikan pada siklus berikutnya. Sedangkan Instrumen yang 
digunakan terdiri dari : 1) Instrumen Penilaian Hasil Belajar mata pelajaran agribisnis ternak umggas petelur (sesuai materi yang telah ditetapkan ) yang menyangkut pengetahuan, sikap dan ketrampilan, 2) Instrumen Wawancara, 3) Instrumen Pengamatan, dan 4) Instrumen Isian oleh Objek (guru dan Siswa).

\section{Hasil dan Pembahasan}

Pembahasan tentang hasil Penelitian Tindakan Kelas yang dilaksanaka kelas XI.2 Agribisnis Ternak Unggas SMK Negeri 2 Negara. Hasil yang dicapai siswa pada tes prasiklus dapat diuraikan sebagai berikut : .

1. Terdapat 14 orang siswa yang memperoleh nilai diatas KKM, dengan katagori tuntas

2..Terdapat 12 orang siswa yang mendapatkan nilai dibawah KKM, dengan katagori belum tuntas

2. Jumlah nilai rata-rata masih dibawah KKM yakni 63,7

3. Ketuntasan belajar mencapai $53,8 \%$

4. Siswa yang belum tuntas mencapai $46,2 \%$

5. Berdasarkan kemampuan siswa yang dicapai pada Prasiklus dapat diuraikan sebagai berikut : :

a. Kemampuan siswa kelas XI Agribisnis ternak unggas pada semester II dalam mengaplikasikan materi pengadaan bibit unggas petelur masih memerlukan banyak latihan dan petunjuuk yang jelas dari guru, karena siswa belum dapat melakukan proses pengadaan bibit unggas petelur dengan sempurna

b. hasil yang dicapai melalui tes prasiklus terutama dalam praktik penanganan bibit yang baru tiba rendah atau belum mencapai nilai standar.

c. Rendah hasil pembelajaran yang dicapai siswa pada Prasiklus karena pengetahuan tentang proses pengadaan bibit unggas petelur belum dipahami dengan baik oleh siswa.

d. Dalam Praktik pengadaan bibit unggas petelur siswa nampak belum dapat merepleksikan pengetahuannya dengan tepat seperti :

1. Persiapan kandang yang ideal : hari pertama yang harus diperhatikan siswa adalah bagaimana mempersiapkan kandang untuk DOC/DOD dengan tepat. Karena kandang merupakan syarat utama untuk kelangsungan hidup DOC/DOD lebih lanjut

2. Menyiapkan penghangat dan cahaya. DOC/DOD yang masih lemah sangat membutuhkan cahaya dan penghangat, hal itu dikarenakan suhu tubuhnya belum bisa menyesuaikan diri. Tidak hanya itu saja bulu DOC?DOD yang masih tipis membuatnya tidak tahan dengan hawa dingin. Oleh sebab itulah penghangat ini dibutuhkan. Cahaya pun dibutuhkan untuk membuat pandangan di malam hari jauh lebih baik. Kandang yang minim cahaya akan membuat tikus dan kucing menjadikan DOC/DOD tersebut sebagai mangsa.

3. Pemberian Vitamin : Cara merawat DOC/DOD anak unggas petelur yang wajib diperhatikan adalah pemberian vitamin. Sifat dari anak unggas terutama ayam petelur ini memiliki ketergantungan yang tinggi terhadap manusia sehingga jika peternak tidak telaten dan terampil maka DOC/DOD ini akan banyak yang mati.

4. Pemberian ransum pakan : Ransum yang bernutrisi tinggi diperlukan bagi tumbuh dan kembang DOC/DOD tersebut. Untuk membuat tubuh DOC/DOD menjadi lebih sehat peternak harus tahu nutrisi apa saja yang dibutuhkan oleh DOC/DOD tersebut, jangan sampai ada nutrisi yang terlewatkan oleh peternak. Siswa dalam hal ini perlu dengan cermat melakukannya dalam pembelajaran.

5. Minum yang cukup : yang tidak kalah penting dan perlu perhatian adalah pemberian minum yang cukup. Tidak memberikan minum secara teratur akan menyebabkan nutrisi tidak bisa diserap secara sempurna.

6. Vaksinasi : Fungsi dari vaksin ini untuk menghindarkan bibit unggas petelur dari berbagai macam penyakit yang bisa membahayakan bahkan berakibat ke kematian DOC/DOD. 
7. Pemberian probiotik : Pemberian Probiotik ini digunakan untuk meningkatkan kebebalan tubuh ayam dan menghindarkannya dari berbagai macam penyakit.

Dalam mengaplikasikan pengetahuan/akademik tersebut diatas dengan praktik nampak kurang menguasai, sehingga hasil belajar yang dicapai rendah. Peragaan dalam bentuk contoh atau model yang berkaitan dengan cara merawat DOC/DOD dengan benar yang disampaikan oleh guru belum dipahami oleh siswa. Dalam hal mengemukakan pendapat dan masalah yang dihadapi dalam pembelajaran keberanian siswa masih kurang.Guru perlu mengevaluasi pelaksanaan pembelajaran dengan melihat kondisi belajar siswa di prasiklus. Siswa memerlukan bimbingan dan tuntunan dari guru agar lebih semangat belajar untuk mencapai hasil belajar yang lebih baik .

Dari hasil prasiklus tersebut dapat diungkapkan beberapa hal sebagai berikut : 1) Capaian nilai tertinggi adalah 71, 2) Capaian nilai terendah adalah 46 , 3) Siswa yang belum mencapai ketuntasan belajar pada prasiklus dilakukan refleksi pada siklus I, 4) Pembelajaran di prasiklus belum menerapkan model Problem Base Learning namun masih bersifat satu arah (teacher Centred) sehingga hasil belajar siswa belum mencapai nilai yang maksimal sesuai yang distandarkan, 5) Pelaksanaan pembelajaran praktik pengadaan bibit anak unggas petelur baru berupa simulasi dengan waktu yang terbatas, dan 6) Penyampaian materi lebih dominan materi akademik (pengetahuan) dan siswa belum dapat mengaplikasikannya dalam praktik dengan baik.

Berdasarkan permasalahan tersebut diatas, perlu dilakukan perbaikan dan melalui Penelitian Tindakan Kelas ini dengan menerapkan model pembelajaran Problem Base Learning pada siklus berikutnya.

Pembelajaran di siklus I dilaksanakan berdasarkan rencana yanga telah dirancang sesuai denganprogram Penelitian Tindakan Kelas ini. Gambaran hasil belajar yang dicapai siswa pada prasiklus menjadi bahan dan acuan dalam melakukan perbaikan-perbaikan di siklus I. Pada siklus I dilaksanakan langkah-langkah pembelajaran sesuai dengan rencana dan menerapan model pembelajaran Problem Base learning dalam pembelajaran agribisnis unggas petelur dilaksanakan dengan langkah-langkah sebagai berikut :

1. Perencanaan

Hasil yang diperoleh pada prasiklus kemudian dilakukan refleksi di siklus I, hasil prasiklus dijadikan dasar untuk melaksanakan perbaikan pelaksanaan siklus I. Oleh karena itu, kegiatan yang dilakukan pada perencanaan siklus I merupakan perbaikan-perbaikan dari kelemahan yang ditemukan sebelumnya. Adapun perencanaan yang dilakukan sebagai berikut:

a. Mempersiapkan materi pelajaran yang akan dibahas pada hari ini yaitu tentang pengadaan bibit anak unggas petelur .

b. Mengecek hasil Prasiklus yang dicapai siswa

c. Mempersiapkan perangkat tes dan observasi yang digunakan dalam penelitian ini,

d. Mempersiapkan siswa yang menjadi Subjek dalam Penelitian Tindakan Kelas ini

e. Menyiapkan tempat yang representatif

2. Pelaksanaan ( Pertemuan Pertama)

a. Melaksanakan Tes Awal (Pretest),

b. Guru menyampaikan tujuan pembelajaran yang akan dicapai.

c. Guru menyampaikan materi pelajaran yang akan dibahas pada hari ini

d. Guru menyampaikan kepada siswa tentang metode/model pembelajaran yang akan digunakan dalam pembelajaran hari ini yaitu model pembelajaran Problem Base Learning,

e. Menyampai kan materi tentang pengadaan bibit anak unggas petelur yang melkiputi :

1. Menentukan jenis starin/ bibit anak Unggas Petelur

2. Menentukan karakteristik masing-masing starin

3. Mempersiapkan materi tentang teknik memperoleh bibit anak unggas petelur

4. Penentuan jadwal kandangan bibit 
5. Persiapan kedatangan bibit

6. Seleksi bibit anak unggas petelur Penanganan bibit anak unggas petelur yang baru datang

Guru menjelaskan prosedur dan langkah-langkah dalam menangani bibit anak unggas petelur yang baru datang dan selanjutnya. Siswa diminta mencermati pengetahuan tentang prosedur dan langkah-langkah dalam menanagani bibit anak unggas petelur dengan seksama Guru mendemonstrasikan tentang prosedur dan langkah-langkah cara menangani bibit anak unggas petelur dan siswa diminta mengamati serta dapat memahaminyaSiswa memperhatikannya dengan antusias Suasana kelas nampak lebih dinamis dari prasiklus Guru memberikan tugas kepada siswa untuk merangkum pengetahuan yang telah disampaikan, Guru menyampaikan lembar tugas untuk dikerjakan siswa Siswa mengerjakan tugas akademik, Guru membimbing siswa dalam mengerjakan tugas, Observer mengamati kegiatan pembelajaran, Guru mengintruksikan kepada siswa agar mengumpulkan tugasnya masing-masing, Mempersiapkan tugas untuk pertemuan berikutnya,Guru Memberikan penghargaan kepada siswa yang telah berhasil dengan baik, Evaluator mencatat hasil pengamatannya

3. Pelaksanaan (Pertemuan Kedua) :

a. Mengecek kesalahan-kesalahan yang terjadi pada pertemuan pertama,

b. Guru memperbaiki kesalahan-kesalahan pada pertemuan pertama,

c. Guru melaksanakan pembelajaran, yang diawali dengan demonstrasi tentang praktik prosedur dan langkah-langkah penanganan bibit anak unggas petelur.

d. Guru mendemonstrasikan diruang praktek tentang prosedur dang langkah-langkah yang meliputi cara mengontrol temperatur suhu ruang kandang bibit anak unggas petelur yang meliputi :

1. Saat suhu telalu dingin dengan melihat tingkah laku bibit

2. Saat suhu terlalu panas

3. Ketersedian pemanas

4. Mengontrol kelembaban kandang bibit

5. Mongontrol kelembaban kandang

e. Siswa diminta memperhatikan langkah-langkah dalam lembar kerja praktk dengan seksama,

f. Guru meminta kepada siswa mengerjakan tugas praktek cara menangani bibit anak unggas petelur sesuai prosedur beserta langkah-langkahnya

g. Siswa menanyakan kepada guru tentang tugas yang belum dipahaminya,Siswa berdiskusi tentang kesulitannya dalam mengerjakan tugas bersama guru,

h. Evaluator bersama peneliti mengamati dan membimbing siswa,

i. Guru memotivasi siswa agar belajar lebih semangat dari sebelumnya,

j. Suasana kelas nampak dinamis dan inovatif, siswa nampak antusias dalam mengerjakan tugas praktek,

k. Guru memperhatikan siswa yang belum dapat menyelesaikan tugas dengan baik,

I. Guru meminta kepada siswa agar menyelesaikan tugasnya karena waktu sudah selesai,

m. Melaksanakan Tes Akhir siklus I,

n. Guru memberikan penghargaan bagi siswa yang telah belajar dengan baik,

o. Evaluator bersama peneliti menyampaikan kepada siswa tentang hasil yang telah dicapai pada siklus I.

\section{Evaluasi :}

Melakukan tes awal dan tes akhir dengan menggunakan perangkat tes yang telah disediakan dan digunakan pada pra siklus, juga pada siklus berikutnya. Setiap awal dan akhir kegiatan pembelajaran dilakukan tes untuk mengetahui perkembangan peningkatan hasil belajar siswa. 


\section{Melakukan observasi :}

Observasi dilaksanakan bersama dengan observer untuk mendapatkan sejumlah informasi yang akan digunakan sebagai bahan evaluasi dan refleksi.Pelaksanaan observasi ini di fokuskan pada kegiatan pembelajaran yang telah berlangsung baik dalam pembelajaran teori maupun dalam pembelajaran praktek. Guru bertindak sebagai observer pada saat yang sama melakukan pengamatan dengan mengisi instrument yang sudah disiapkan. .

6. Melakukan Refleksi :

Refleksi dilakukan bagi siswa yang belum mencapai ketuntasan untuk meningkatkan hasil belajarnya.pada siklus I Dari hasil paparan siklus I diatas dapat dijabarkan sebagai berikut :Hasil Siswa : a) Terdapat 21 orang siswa yang memperoleh nilai diatas KKM, dengan kata gori tuntas, b) Terdapat 5 orang siswa yang mendapatkan nilai dibawah KKM, dengan katagori belum tuntas, c) Jumlah nilai rata-rata yakni 75,3, d) Ketuntasan belajar mencapai $80,8 \%$, dan e) Siswa yang blm tuntas adalah $19,2 \%$

Hasil Siklus I tersebut terjadi peningkatan dari hasil prasiklus. Setelah ndilaksanakannya Model pembelajaran Problem Base Learning bagi siswa dan siswa dapat menunjukkan kemampuannya dalam pembelajaran seperti : 1) Cara menangani bibit bari tiba hingga penanganannya dalam kandang, 2) .Penyiapan jumlah tempat minum beserta minumannya, 3) Cara memulihkan tenaga bibit, 4) Pengaturan susu kandang agar bibit dapat dengan nyaman di dalam kandang, 5) Pemberian pakan dan vitamin serta nutrisi yang sesuai, 6) Guru dalam mengajar lebih banyak memotivasi siswa, agar lebih semangat dalam belajar, dan 7) Peningkatan hasil belajar siswa yang dicapai pada siklus I merupakan cermin dari keberhasilan pelaksanaan model pembelajaran Probelem Base learning.

Dari hasil siklus I tersebut dapat diungkapkan beberapa hal sebagai berikut : a) Capaian nilai tertinggi adalah 81 , b) Capaian nilai terendah adalah 65 , c) Siswa yang mencapai ketuntasan belajar pada siklus I ada peningkatan dari prasiklus sebanyak $27 \%$, d) Pembelajaran di siklus I telah menunjukkan suasana belajar yang lebih inovatif dari prasiklus, e) Pelaksanaan pembelajaran praktik pengadaan bibit unggas petelur berlangsung sesuai prosedur, dan f) Penyampaian materi oleh guru dengan menerapkan model pembelajaran Problem Base Learning membuat siswa lebih aktif dalam belajar. Namun masih ada 5 orang siswa pada siklus I yang belum mencapai ketuntasan belajar. Tindakan dilanjutkan pada siklus II.

Pada siklus II kegiatan Pembelajaran Agribisnis Tertnak Unggas Petelur dengan materi pengadaan bibit unggas petelur dilaksanakan dengan menerapkan model pembelajaran Problem Base Learning secara konsisten. Model pembelajaran Problem Base learning telah terbukti mampu meningkatkan hasil belajar siswa kelas XI Agribisnis ternak ungags pada mata pelajaran agribisnis ternak unggas petelur dengan baik. Bagi siswa yang belum mencapai ketuntasan belajar pada siklus I dilakukan perbaikan pada siklus II. Pada siklus II Peneliti melakukan pemantapan terhadap pembelajaran dengan memberikan bimbingan kepada siswa melalui refleksi. Dalam melakukan perbaikan tersebut peneliti menerapkan langkah-loangkah sebagai berikut :

1. Perencanaan

Kegiatan yang dilakukan pada perencanaan siklus II merupakan perbaikan-perbaikan dari kelemahan yang ditemukan sebelumnya. Perbaikan yang dilakukan adalah sebagai berikut :

a. Mengkondisikan siswa yang belum mencapai ketuntasan belajar pada siklus I sebanyak 5 orang siswa.

b. Membimbing siswa yang sudah mencapai ketuntasan pada siklus I sebayak 21 orang mengerjakan tugas baru praktek penanganan benih anak unggas petelur

c. .Mempersiapkan suhu dan kelembaban kandang serta ventilasi udara

d. Mempersiapkan kebutuhan pakan dan minum bibit yakni :

1. Cara menyiapkan pakan dan air minum untuk bibit

2. Menentukan jadwal pemberian pakan 
3. Mempersiapkan bibit atas resiko kematian

4. Pengaturan waktu pembersihan kandang

5. Mengecek kondisi benih apakah sdh kuat atau masih lemah

6. Mempeersiapkian pakan untuk perode grower

7. Mempersiapkan obat anti stres.

\section{Pelaksanaan ( Pertemuan I)}

a. Guru melakukan tes awal siklus II (Pretest)

b. Guru menjelaskan tentang hasil pertemuan siklus I

c. Guru menjelaskan tujuan pertemuan siklus II

d. Guru menyampaikan materi yang dipelajari pada siklus II untuk siswa yang 5 orang,

e. Guru menyampaikan materi yang dipelajari pada siklus II untuk yang 21 orang

f. Materi disampaikan guru kepada siswa yang 5 orang tentang cara menangani bibit anak unggas petelur yang terdiri dari : .

g. cara menangani bibit anak unggas petelur.

h. Guru menyajikan gambar langkah-langkah cara menanagani bibit anak unggas petelur

i. Siswa diminta membuat jadwal pemberian pakan dan penyediaan air minum.

j. Siswa diminta mengecek kondisi bibit anak unggas petelur

k. Siswa diminta mengatur suhu ruangan kandang

I. Siswa diminta membersihkan kandang

$\mathrm{m}$. Siswa melaksanakan tugas dengan bimbingan guru.

n. Siswa melakukan perbaikan atas kesalahan siklus I dengan dibimbing oleh guru,

o. Guru membagikan materi untuk dikerjakan oleh siswa yang 26 orang yaitu :

1. Mengecek kesehatan bibit

2. Menjga kebersihan kandang

3. Memberi obat anti strs

4. Mengatur jadwal pemberian pakan

p. Siswa melaksanakan tugas dan menyelesaikan tugas yang diberikan guru dengan tekun.

q. Peneliti bersama evaluator mengamati siswa yang sedang belajar tentang cara penanganan bibit dalammasa pertumbuhan (growing).

r. Peneliti bersama guru dan evaluator membimbing sisw

s. a, untuk melakukan proses penanagan bibit anak unggas petelur dengan baik.Peneliti bersama evaluator mengamati siswa yang sedang belajar praktik penanganan bibit dalam masa pertumbuihan (21 orang),

t. Peneliti memberikan bimbingan secara intensif dalam upaya meningkatkan hasil belajar yang lebih baik pada siklus II.

u. Guru menuntun siswa yang belum mencapai ketuntasan belajar di siklus I agar lebih berani mengemukakan masalah yang dihadapinya terkait dengan kesulitan belajar .

v. Guru melihat hasil belajar siswa (5) orang dan mengoreksinya.

w. guru meminta kepada siswas (5) orang bergabung dengan siswa yang 21 orang mengikuti praktek brooding

x. Pelaksanaan ( Pertemuan Kedua)

1. Guru melihat kembali hasil pertemuan pertama,

2. Hasil pertemuan I di analisis kembali dan terlihat adanya peningkatan hasil belajar yang dicapai oleh siswa,

3. Siswa mencermati kembali hasil kerjanya dan bagi siswa yang hasilnya belum sempurna dilakukan bimbingan oleh guru,

4. Guru memberikan koreksi terhadap perbaikan hasil pertemuan I dan nampak adanya peningkatan.

5. Guru mengevaluasi hasil yang telah dicapai oleh siswa.

6. Guru meminta kepada siswa agar hasil yang dicapai siswa dibuat laporannya.

7. Siswa ditugasi mendeskripsikan hasil kerja yang telah selesai agar lebih sempurna dan operasional,

8. Guru memberikan penghargaan kepada siswa yang telah berhasil dengan baik, 
9. Melaksanakan test akhir ( Posttest Siklus II)

10. Setiap awal dan akhir siklus dilakukan test untuk mengetahui daya serap siswa terhadap materi yang diajarkan

y. Observasi Observasi dilakukan untuk mendapatkan sejumlah informasi yang akan digunakan sebagai bahan evaluasi dan refleksi.

z. Refleksi

Pelaksanaan refleksi terhadap siswa untuk mencapai ketuntasan belajar pada mata pelajaran agribisnis Unggas petelur yang di pelajari di siklus II.

\section{Evaluasi :}

Pelaksanaan evaluasi terhadap kegiatan pembelajaran dengan menggunakan perangkat yang telah disiapkan berupa instrumen tes dan digunakan pada pra siklus, juga pada siklus berikutnya.

Dari hasil paparan siklus II diatas dapat dijabarkan sebagai berikut :

1.Sebanyak 26 orang siswa yang memperoleh nilai diatas KKM, dengan kata gori tuntas

2.Pada siklus II tidak ada lagi siswa yang belum tuntas dalam pembelajaran dan peningkatan hasil belajar agribisnis unggas petelur dengan materi pengadaan bibit anak unggas petelur telah dicapai dengan baik.

3.Jumlah nilai rata-rata yakni 80,1

4. Ketuntasan belajar siswa $=100 \%$.

5.Siswa yang belum tuntas $=0 \%$

Hasil Siklus II tersebut dapat diuraikan sebagai berikut: Siswa telah menunjukkan kemampuannya dalam upaya meningkatklan hasil mata pelajaran agribisnis unggas petelur pada materi pengadaan bibit unggas

1. Petelur dengan baik pada siklus II

Pemahaman siswa terhadap materi tentang pengadaan bibit anak unggas petelur telah menun jukkan peningkatan dengan baik dan model pembelajaran Problem Base Learning mampu menuntun siswa dalam berpikir kreatif dan inovatif dalam mengorganisasikan materi pelajaran sehingga dapat dipahaminya dengan baik.

2. Dalam memaknai konsep materi pengadaan bibit anak unggas petelur berdasarkan hasil siklus II telah terjadi peningkatan dari Siklus I dan siswa antusias dalam mengikuti pembelajaran baik pelajaran teori maupun praktik

3. .Siswa menyenangi belajar dengan model Problem Base Learning karena siswa diarahkan untuk belajar secara aktif, memahami konsep, hubungannya dengan materi lainnya dan terlibat melalui proses intuitif.

4. Semangat belajar siswa tercermin dari suasana belajar siswa yang menunjukkan antusias untuk menemukan dan mengorganisasikan hasil pembelajarannya.

5. Guru mengajar lebih banyak memotivasi siswa, dalam pembelajaran dan guru lebih banyak memberi kesempatan kepada siswa untuk bereksplorasi dan berdiskusi untuk menyelesaikan tugasnya,

6. Siswa mulai merespon pertanyaan guru, sehingga mampu meningkatkan pemahamannya dalam belajar praktek persiapan kandang unggas petelur.

7. Ketika guru memberi kesempatan kepada siswa untuk bertanya, siswa merespon dan guru memberikan penjelasan.

8. Guru telah mampu meningkatkan hasil belajar siswa melalui penerapan model pembelajaran Problem Base Learning

9. Siswa nampak sangat terampil dan menyenangi bekerja di ruang praktek penanangananbibit anak unggas petelur dalam masa pertumbuhannya.

Pembelajaran pada siklus II telah mencapai hasil yang maksimal. Penerapan model pembelajaran Problem Base Learning terbukti mampu meningkatkan hasil belajar siswa dan siswa belajar dengan aktif baik dalam pembelajaran teori maupun praktek. Pelaksanaa refleksi serta bimbingan dari guru membuat siswa semakin meningkatkan hasil belajarnya, dari setiap siklus. 
Hasil Penelitian Tindakan Kelas (PTK) yang telah dilaksanakan di SMK Negeri 2 Negara tentang peningkatan hasil belajar siswa terhadap mata pelajaran agribisnis ternak unggas petelur dengan materi pengadaan bibit unggas petelur yang telah dicapai dari siklus ke siklus dapat di paparkan bahwa Hasil belajar siswa dapat disajikan sebagai berikut : a) Nilai rata-rata adalah : 75,3, b) Ketuntasan belajarnya yang dicapai siswa adalah : 80,8\%, c) Sebanyak 21 orang siswa yang telah mencapai ketuntasan dalam belajar sehingga hasil belajarnya menjadi meningkat dengan baik dari prasiklus, dan d) Sebanyak 5 orang siswa $(19,2 \%)$ siswa yang belum mencapai ketuntasan dalam belajar sehingga perbaikan berlanjut pada siklus II.

Terjadinya peningkatan hasil belajar siswa pada siklus I karena Peneliti menerapkan model pembelajaran Problem Base Learning secara konsisten. Hasil yang dicapai pada sikls I masih perlu ditingkatkan. Untuk itu bimbingan kepada siswa dalam bentuk tindakan refleksi dilakukan untuk mencapai peningkatan hasil yang lebih baik.

Hasil belajar siswa pada siklus II nampak meningkat secara signifikan. Setelah dilakukan bimbingan dalam bentuk refleksi terhadap siswa pada siklus II ini maka kemampuan siswa baik dibidang akademik maupun dalam pembelajaran praktek meningkat dengan baik. Siswa menunjukkan sikap mandiri dalam belajar dan mampu mengorganisasikan kelompok belajar secara mandiri. Materi yang dipelajarinya dapat dipahaminya dengan baik. Adapun hasil belajar yang dicapai siswa pada siklus II sebagai berikut : a) Nilai rata-rata adalah 80,1, b)Ketuntasan siswa dalam belajar adalah : $100 \%$, c) Pada siklus II semua siswa telah menuntaskan pembelajarann dengan baik, dan d) Siswa telah menunjukkan kemampuan belajarnya dengan maksimal dan menyenangkan.

Dari data yang diperoleh pada siklus I, II, terhadap peningkatan hasil belajar siswa kelas XI.2 Agribisnis ternak unggas semester II SMK Negeri 2 Negara, telah menunjukkan peningkatan, dan adanya pengaruh yang positif terhadap penerapan model pembelajaran Problem base Learning dalam meningkatkan hasil belajar siswa. Dengan demikian penerapan model Pembelajaran Problem Base loearning telah terbukti keberhasilannya dengan baik. Hal ini didukung oleh penelitian yang pernah dilakukan oleh Jayadiningrat, M. G (2018) bahwa penerapan Problem Based Learning dapat meningkatkan keterampilan memecahkan masalah pada mata pelajaran Kimia di kelas XI IPA SMAN 1 Weluli.

\section{Simpulan dan Saran}

Berdasarkan Pelaksanaan Penelitian Tindakan Kelas (PTK), yang dilaksanakan di kelas XI Agribisnis Ternak Unggas pada Semester II SMK Negeri 2 Negara, telah berlangsung sesuai dengan program yang direncanakan dan telah menghasilkan suatu kesimpulan. Hasil yang diperoleh bahwa dengan penerapan model pembelajaran Problem Base Learning dalam pelajaran aguibisnis unggas bertelur dengan materi pengadaan bibit unggas bertelur, ternyata tepat dan hasil perolehan nilai siswa dapat meningkat serta aktivitas belajar siswa telah menunjukkan peningkatan dari siklus I, ke siklus II. Pencapaian materi pembelajaran pengadaan bibit anak unggas bertelur, melalui penerapan model pembelajaran problem base learning, secara signifikan dapat meningkatkan hasil belajar siswa dan kemampuan siswa dalam menanangani bibit anak unggas bertelur secara prosedur dan menerapkannya dalam praktek melalui penelitian ini dapat dilakukannya dengan sempurna. Peningkatan hasil belajar siswa yang dicapai dalam Penelitian Tindakan Kelas ini terangkum dalam tabel rekapitulasi hasil.

Berdasarkan hasil penelitian, maka dapat disarankan beberapa hal antara laian sebagai berikut:

1. Penerapan model belajar yang sesuai dengan materi pelajaran yang diajarkan dapat meningkatkan hasil belajar siswa. Untuk itu disarankan agar guru tetap memilih dengan cermat metodaatau model belajar yang tepat dan sesuai dengan mata pelajaran yang diajarkannya.

2. Penelitian Tindakan Kelas baik dilakukan untuk memperbaiki kelemahan - kelemahan dalam pembelajaran. Disarankan guru perlu melakukan Penelitian Tindakan Kelas untuk meningkatkan mutu pembelajaran. 
3. Kepada Guru yang ingin melaksanakan Penelitian Tindakan Kelas disarankan dapat menghimpun data kelas yang akan menjadi Subjek Penelitian untuk memperlancar pelaksanaan Penelitian.

4. Kepada guru mata pelajaran Kejuruan pada bidang keahlian Agribisnis ternak dalam rangka meningkatkan mutu pembelajaran dan hasil belajar siswa perlu melakuan Penelitian Tindakan Kelas karena tidak menggangtgu aktivitas pembelajaran di sekolah

5. Bagi siswa, agar tetap semangat belajar, mempunyai motivasi belajar yang tinggi untuk mencapai hasilnya belajar yang lebih optimal.

6. Bagi sekolah dapat memfasilitasi guru-guru yang akan melakukan Penelitian Tindakan Kelas karena dari hasil dan pengalaman yang diperoleh dapat dijadikan input dalam rangka mengembangkan kurikulum dimasa yang akan datang.

\section{Daftar Pustaka}

Arikunto, Suharsimi, 1989, Penilaian Program Pendidikan, Proyek Pengembangan $\quad$ LPTK Depdikbud, Dirjen Dikti.

Arikunto, Suharsimi, 1993, Manajemen Mengajar Secara Manusiawi, jakarta rineksa Cipta.

Basiran, Mokh. 1999. Apakah yang Dituntut GBPP Bahasa Indonesia Kurikulum 1994 ?. Yogyakarta: Depdikbud

Darjowidjojo, Soenjono. 1994. Butir-butir Renungan Pengajaran Bahasa Indonesia sebagai Bahasa Asing. Makalah disajikan dalam Konferensi Internasional Pengajaran Bahasa Indonesia sebagai Bahasa Asing. Salatiga: Univeristas Kristen Satya Wacana

Degeng, I.N.S. 1997. Strategi Pembelajaran Mengorganisasi Isi dengan Model Elaborasi. Malang: IKIP dan IPTDI

Depdikbud. 1995. Pedoman Proses Belajar Mengajar di SD. Jakarta: Proyek Pembinaan Sekolah Dasar,

Departemen Pendidikan nasional (2003). Undang-Undang nomor 23 tahun 2003 tentang Sistem Pendidikan Nasional Jakarta

Hidayat, Sholeh (2003). Media dan sumber Pembelajaran. Makalah pada Diklat Guru dan Kepala sekolah-Dindik Propinsi Banten,

Imam Syafi'e. 1993. Terampil Berbahasa Indonesia I. Jakarta: Departemen Pendidikan dan Kebudayaan.http://www.ditplb.or.id/new/index.php, Model- model Penelitian Tindakan Kelas . Direktorat Pendidikan Luar Sekolah. Jakarta, diunduh 15 Juni 2013.

Jayadiningrat, M. G., \& Ati, E. K. (2018). Peningkatan Keterampilan Memecahkan Masalah Melalui Model Pembelajaran Problem Based Learning (Pbl) Pada Mata Pelajaran Kimia. Jurnal Pendidikan Kimia Indonesia, 2(1), 1-7.

Kentut,Drs. 2004. Prinsif Pengembangan Media, Pustekom. Jakarta.

Machfudz, Imam. 2000. Metode Pengajaran Bahasa Indonesia Komunikatif. Jurnal Bahasa dan Sastra UM

Moeleong, Lexy J. 2000. Metodologi Penelitian Kualitatif. Bandung: PT. Remaja Rosyda Karya.

Nasution, Prof,Dr,MA. 1986. Didaktik Asas Mengajar, Bandung Jemmars. 
Sapriya. Dkk, 1999, Studi Tentang Media Pembelajaran Nilai dalam mata pelajaran PPKN di SLTP dan SMU Bandung ( Laporan penelitian, tidak diterbitkan.)

Mulyasa, E.2007. Kurikulum Tingkat Satuan Pendidikan. Bandung: PT. Remaja Rosdakarya.

Yasin, Martinis. 2007. Desain Pembelajaran Berbasis Tingkat Satuan Pendidikan. Jakarta: Gaung Persada Press. 